\title{
Politik Identitas Etnis Batak Toba dalam Novel Bulan Lebam di Tepian Toba Karya Sihar Ramses Simatupang
}

\author{
Hendra Sigalingging \\ hensig@staff.ukdw.ac.id \\ Universitas Kristen Duta Wacana Yogyakarta
}

\begin{abstract}
Abstrak. Artikel ini merupakan hasil analisis politik identitas dalam konteks masyarakat Batak Toba. Objek kajian penelitian ini dikhususkan pada politik identitas etnis Batak dalam novel Bulan Lebam di Tepian Toba karya Sihar Ramses Simatupang. Penulis mengumpulkan data yang ada dalam novel lalu melakukan analisis isi dengan pendekatan identitas kultural Stuart Hall. Dalam penelitian ini, penulis menggunakan dua konsep yang ditawarkan oleh Stuart Hall, yaitu representasi dan identitas etnis atau kultural. Dari pembahasan yang dilakukan, maka ada dua hasil penelitian ini. Pertama, representasi identitas etnis Batak dalam novel ini memiliki sisi esensialis. Novel ini merepresentasikan persoalan-persoalan yang hadir dalam kehadiran Pabrik kertas Indorayon di Tanah Batak. Tidak berhenti di situ saja, novel ini pun mengkonstruksi identitas Batak dengan menawarkan alternatif identitas etnis Batak yang lebih positif. Kedua, persoalan tanah dan konstruksi identitas etnis Batak yang dibangun oleh novel atau pengarangnya adalah identitas manusia Batak yang ajakan untuk kembali pada nilai-nilai tradisi Batak yang sudah ada. Hal ini ditambah dengan pengembangan pola pikir kritis yang dapat meningkatkan posisi tawar manusia Batak dalam menghadapi wacana Pabrik kertas. Selain itu, keterlibatan dalam bidang politik menjadi tawaran pengarang dalam politisasi identitas etnis Batak Toba agar dapat membentuk wacana bandingan berhadapan dengan wacana pabrik kertas.
\end{abstract}

Kata kunci: representasi, politik identitas, identitas etnis

\section{Pendahuluan}

Sastra dan realitas sosial merupakan dua entitas yang selalu terkait. Keterkaitan keduanya bisa dalam bentuk kausalitas. Hubungan ini dapat dianggap sedemikian kuatnya, sehingga satu narasi sastra dipandang sebagai refleksi dari struktur sosial di mana seorang pengarang menghasilkan karyanya. Georg Lukacs (via Kleden, 2004) menjelaskan bahwa dalam fungsinya, sastra dapat berperan sebagai refleksi realitas sosial dengan teknik mimesis. Refleksi ini mengandung respons dan reaksi aktif terhadap realitas sosial yang direpresentasikannya.

Salah satu refleksi yang hadir adalah persoalan terkait identitas. Identitas menjadi persoalan yang kerap direprsentasikan oleh pengarang dalam karyanya. Hall (1993) memaknai identitas sebagai suatu produksi, bukan esensi yang tetap dan menetap. Dengan begitu, identitas selalu berproses, selalu membentuk, di dalam bukan di luar representasi. Hal ini menandakan jika identitas bukanlah sesuatu yang tetap dan memiliki "pakem" utuh yang akan bertahan dalam perkembangan zaman. Identitas bersifat "cair" dan akan selalu berproses sesuai dengan dinamika dan wacana yang mengelilinginya.

Dalam kutipan Hall di atas dapat ditarik dua hal. Pertama, identitas akan selalu berproses dan bersifat cair. Ini bisa dimaknai jika identitas merupakan entitas yang tidak otonom dan bersifat mutlak. Kedua, adalah pembentukan identitas berlangsung dalam representasi. Representasi yang dimaksud tentu 
saja, satu ruang yang tercipta dengan tujuan menegosiasikan, mengkaji ulang, ataupun mengkonstruksi identitas itu sendiri. Konstruksi identitas inilah yang akan terlihat melalui representasi. Dalam kajian budaya sendiri, persoalan identitas akan bermuara pada anti-esensialis. Dalam konteks ini, identitas dilihat sebagai hasil "bentukan" wacana yang mengubah maknanya menurut waktu, tempat, dan penggunaan (Barker, 2000).

Pertemuan antarwacana yang memengaruhi proses pembentukan identitas tentu saja menghadirkan satu ruang sebagai medianya. Dalam konteks ini, pertemuan antarwacana bisa dilihat atau didapat dari seluruh varian wacana yang ada, termasuk sastra. Sastra bisa dikatakan sebagai wacana yang mengupayakan pembentukan identitas, mengidentifikasi identitas, atau merepresentasikan pertarungan identitas. Sastra diposisikan sebagai teks atau wacana yang ikut ambil bagian sebagai pembentuk suatu identitas. Dalam dimensi ini, sastra dianggap sebagai upaya pembentukan identitas atau politik identitas.

Hal ini menstimulan penulis untuk melihat identitas etnis batak Toba dengan menggunakan karya sastra, secara khusus adalah novel. Salah satu novel yang bisa menjadi representasi politik identitas etnis Batak adalah novel "Bulan Lebam di Tepian Danau Toba". Novel yang berlatarkan budaya batak ini dengan cukup dominan membawa identitas batak sebagai entitas utama penceritaan. Novel yang dituliskan oleh Sihar Ramses Simatupang (selanjutnya ditulis Sihar) ini merepresentasikan pertarungan identitas di dalamnya. Untuk itulah, penulis melibatkan novel ini sebagai objek kajian penulis untuk menganalisis politik identitas, secara khusus identitas Batak Toba.

Salah satu wacana yang direpresentasikan dalam novel ini adalah pertarungan identitas Batak melawan wacana industri. Wacana industri yang direpresentasikan adalah PT. Indorayon Inti Utama (selanjutnya disingkat IIU). PT IIU dihadirkan dengan sebutan "pabrik kertas". Merujuk hal inilah, penulis pada akhirnya memfokuskan PT.IIU sebagai persoalan batak yang berhubungan dengan identitas etnis Batak Toba. Oleh karena itu, hal ini bisa dibaca sebagai masyarakat batak di tanah samosir versus PT. IIU yang mewakili wacana kapital. Pertarungan wacana yang ada di dalam novel inilah yang menarik penulis untuk melibatkannya dalam analisis politik identitas

\section{Metode}

Objek kajian penelitian ini dikhususkan pada politik identitas etnis Batak dalam novel Bulan Lebam di Tepian Toba karya Sihar Ramses Simatupang. Penulis mengumpulkan data yang ada dalam novel lalu melakukan analisis isi dengan pendekatan identitas kultural Stuart Hall. Dalam penelitian ini, penulis menggunakan dua konsep yang ditawarkan oleh Stuart Hall, yaitu representasi dan identitas etnis atau kultural.

\section{Hasil dan Pembahasan}

\section{Analisa Naratif : Representasi Persoalan PT.IIU dalam Novel Bulan Lebam di Tepian Toba.}

Penulis mencoba melihat kasus PT.IIU ini menjadi wacana yang telah menjadi "konsumsi" publik khususnya dalam masyarakat Batak Toba. Inilah yang akhirnya membuat beberapa orang untuk terlibat dalam wacana PT.IIU, termasuk Sihar Ramses Simatupang sebagai novelis. Dengan novelnya ini, Sihar ikut dalam dinamika wacana PT.IIU dan identitas etnis Batak Toba. Novel ini jelas menunjukkan upaya pemosisiannya dalam 
merepresentasikan dan merespon wacana PT.IIU. Dalam rangka inilah, novel ini menenujukkan upayanya melalui penciptaan paradigma bandingan. Analisis pertama yang dilakukan di sini adalah melihat representasi PT.IIU dalam novel. Dalam novel ini sendiri, Sihar hanya menggunakan istilah pabrik kertas, bukan PT.IIU. Oleh karena itu, penulis akan menggunakan istilah "pabrik kertas" dalam analisis yang terkait narasi dalam novel.

Representasi pertama adalah sistem jaringan kekuasaan yang mendeksripsikan proses penaklukkan Tano Batak oleh perusahaan. Hal ini dideskripsikan dalam novel ini melalui tokoh Ganda.

"Ganda hanya kesal karena perusahaan itu hanya datang ke pihak kepala kampung. Mendatangi Amang Impal dan stafnya. Lalu, pihak kepala kampung mengumumkan kepada setiap orang, mengajak mereka berembuk dan berdiskusi" (Simatupang, 2009: 56).

Penokohan tokoh Ganda menjadi penanda proses kekuasaan yang diterapkan oleh pihak perusahaan kertas. Perusahaan hanya menundukkan kepala Kampung untuk membuat keputusan sepihak terkait urusan tanah ataupun urusan masuknya perusahaan kertas tersebut. Jika dilihat dalam analisis sebelumnya, upacara pago-pago direpresentasikan dalam novel. Di sini, pendekatan yang digunakan oleh perusahaan adalah pendekatan kekuasaan. Pago-pago sendiri menjadi cara PT.IIU untuk memanfaatkan ritus adat ini untuk penguasaan lahan.

Representasi terkait wacana industri yang diwakili oleh PT.IIU dalam novel ini, juga menghasilkan resistensi. Resistensi terhadap keberadaan pabrik kertas dalam novel ini dihadirkan melalui tokoh Ganda. Saat berembuk dengan kepala kampung yang mewakili perusahaan, Ganda menolak rencana tersebut.

"Saya sebagai orang bodoh yang mewakili kampung ini mau bertanya, kenapa kami tak ditemui di saat ada persetujuan dari pihak kepala kampung soal izin menanam pohon di sini. Kami tak tahu terjadinya pertemuan itu, tiba-tiba saya diminta persetujuan ini. Terus terang saya menolak. Saya harap saudarasaudara semua yang tak tahu asal muasal persoalan ini untuk menolak juga..."ujar Ganda. Orang-orang kampung bersuara di belakang Ganda dan mengeluarkan dukungan yang sama terhadap gagasan Ganda" (Simatupang, 2009: 56).

Upaya yang dilakukan oleh tokoh Ganda merupakan ajakan untuk menolak keberadaan PT.IIU. Ganda menjadi pioner penolakan karena pertimbangan masyarakat yang tidak dilibatkan dalam keputusan pendirian perusahaan. Tokoh Ganda pun mendapat pengakuan dan dukungan dari masyarakat yang ada pada saat itu.

Kutipan ini menghadirkan tokoh Ganda sebagai manusia Batak yang tidak menerima kehadiran operasional pabrik kertas begitu saja. Ia pun dihadirkan sebagai manusia Batak yang memiliki sikap menolak keputusan Kepala Kampung yang tidak melibatkan masyarakat dalam kebijakan tersebut. Penolakan Ganda terhadap operasional pabrik kertas dalam kutipan ini masih dalam rangkanya sebagai korban manipulasi yang dilalukan oleh kepala kampung. Dalam kutipan ini masih sebatas sebagai korban manipulasi, belum merepresentasikan perlawanan manusia Batak dalam menghadapi persoalan pabrik kertas.

Resistensi selanjutnya pun masih dilanjutkan oleh Ganda dengan dukungan masyarakat yang ada.

"Saya minta agar saudara semua tenang” tutur kepala kampung. 
"Tidak, kami tidak tenang. Sebelum demonstrasi terjadi seperti di kampungkampung lain, kami menyatakan menolak penanaman pohon di kampung ini ..."

"Saya sepakat dengan Ganda, saya juga tak setuju"

"Saya juga, Amang ..."

"Maafkan kami, tapi Amang harus tahu bagaimana jadinya kalau kita terima tawaran pabrik itu. Kampung lain sudah resah, Amang. Kami pun menolak.." ujar lelaki lain" (Simatupang, 2009: 56).

Kutipan di atas secara eksplisit mendeskripsikan penolakan yang dipimpin oleh Ganda. Masyarakat kampung pun dihadirkan sebagai sekumpulan orang yang mematuhi omongan dari si pemimpin ide saat itu (tokoh Ganda). Kekhawatiran yang dirasakan oleh penduduk kampung merupakan dampak dari keresahan yang dialami oleh kampung tetangga. Hal inilah yang membantu masyarakat untuk menolak pabrik kertas. Tokoh Ganda menjadi tokoh terdepan yang sangat menolak pembukaan lahan atau penanaman tanaman di daerah tersebut.

Di sini cukup terlihat kolektivitas yang mendasari penolakan keberadaan pabrik kertas ini. Jika menilik dengan konsep Hall inilah yang dilihat sebagai identitas etnis dalam bentuk tradisionalnya, yaitu suatu usaha perlawanan yang menggunakan kesamaan kode-kode budaya yang ada dalam masyarakat tersebut. Berdasarkan pada nasib yang sama dengan masyarakat Batak di kampung lainnya, Ganda menolak operasional pabrik kertas di kampungnya. Penolakan ini pada akhirnya membuahkah hasil yang positif.

"Beberapa kali saja perusahaan itu datang lagi ke kampung. Dua minggu setelahnya, perusahaan itu tak lagi muncul. Yang terdengar kemudian adalah pergolakan dari masyarakat di kampung lain baik yang menolak perusahaan itu berdiri di kampung lain" (Simatupang, 2009: 57).

Representasi penolakan masyarakat Batak Toba telah direspon oleh masyarakat di wilayah lainnya. Hal ini didasari dengan dampak lingkungan yang telah terjadi di kampung lainnya. Kesadaran kolektif hadir karena distimulan oleh tokoh Ganda yang berarti jika masyarakat Batak toba masih bisa mempertahankan tanahnya. Hal ini juga merepresentasikan masyarakat Batak Toba yang tidak langsung terjebak dan menerima tawaran dunia industri. Walau resistensi ini tidak dibahas terlalu dominan dalam novel ini, setidaknya dua kutipan di atas merepresentasikan kesadaran kolektif masyarakat Batak Toba terhadap perjuangan tanah milik keluarga atau tanah adatnya.

Representasi terkait dengan perlawanan terhadap pabrik kertas pun dilakukan secara berkelompok. Hal ini merepresentasikan kolektivitas perlawanan masyarakat Batak Toba terhadap keberadaan PT.IIU. Inilah yang terlihat dalam kutipan berikut.

"Tak wajar bagiku, karena aku sedang bercerita tentang suami yang kucintai.

Waktu itu, selain Ganda, banyak lagi lelaki lain datang memprotes pabrik kertas yang limbah pulp-nya sampai membuat kotor seluruh sungai hingga ke Danau Toba. Datu pun sepertinya ikut. Bahkan kalau saja tak dilarang abangmu, bapakmu juga sudah akan berangkat untuk memprotes ulah pabrikpabrik itu, Monang”( Simatupang, 2009: 56).

Kutipan di atas menjadi representasi penolakan masyarakat terhadap PT.IIU. Kolektivitas yang diperlihatkan pada kutipan ini menjadi satu penanda jika kesamaan identitas mendasari penolakan terhadap pabrik kertas. Banyaknya orang yang terlibat dalam demonstrasi penolakan pabrik kertas dalam novel menjadi representasi yang sama dengan yang terjadi dalam tatanan dunia riil. Kolektivitas dalam melakukan suatu gerakan 
perlawanan dengan menggunakan kesamaan identitas etnis ini pula yang dihadirkan dalam novel ini.

Selain persoalan perjuangan dalam melakukan aksi penolakan, kutipan ini mendeskripsikan dampak negatif pabrik terhadap lingkungan di Tano Toba. Pabrik kertas dalam novel ini direpresentasikan telah mengotori sungai dan Danau Toba. Dampak lingkungan di Tano Toba inilah yang menstimulan masyarakat untuk menolak pabrik kertas.

"Monang baru mendengarnya. Dia juga mendengar dari Pulau Jawa sana tentang kabar demonstrasi yang sampai diwarnai oleh moncong senjata. Aksi protes terhadap pabrik kertas yang terjadi di Tanah Batak bahkan sempat menimbulkan korban" (Simatupang, 2009: 56).

Protes masyarakat Batak telah tersiar hingga ke Tanah Jawa. Ini sekaligus menandakan jika persoalan yang terjadi di Tanah Toba telah menjadi konsumsi nasional. Artinya, gerakan protes yang terjadi dalam masyarakat Batak telah mendapat respon dari luar Tanah Batak. Selain itu, representasi perlawanan yang dilakukan oleh masyarakat kampung Batak telah dipublikasi melalui media. Hal inilah yang membuat kasus PT.IIU tidak hanya terbatas pada lingkup masyarakat Batak Toba. Hal inilah yang direpresentasikan pada kutipan berikut.

"Monang salut, Ganda punya wawasan dan sikap juga! Namun, Monang yakin tak akan ada nama Ganda di saat Koran menyebutkan nama penduduk yang tewas dalam pergolakan di kampung” (Simatupang, 2009: 57).

Ada empat hal yang menurut penulis penting dilihat dalam representasi ini. Pertama, Kalimat "Monang salut, Ganda punya wawasan dan sikap juga" menjadi satu penanda jika secara internal, warga kampung memiliki kesadaran bersama dalam menolak pabrik kertas. Artinya, perlawanan terhadap pabrik kertas dimulai dari persoalan dan kesadaran yang terbangun dalam komunitas masyarakat itu sendiri. Kedua, keterlibatan koran (media) dalam persoalan pabrik kertas. Kemunculan Koran menjadi penanda jika kasus pabrik kertas ini telah mendapatkan atensi dari kalangan dari luar warga kampung (masyarakat Batak). Ketiga, adanya klausa "tak akan ada nama Ganda di saat Koran menyebutkan nama penduduk yang tewas " merujuk pada peristiwa penembakan yang terjadi di Sumatera Utara. Ini mereprsentasikan korban penembakan yang terjadi sewaktu demonstrasi menuntut penutupan PT. IIU.

Peristiwa ini menurut penulis merujuk pada peristiwa 5 November 1993. Manalu (2009: 217) menjelaskan bahwa dalam peristiwa ini, 13 nyawa melayang di Bulu Silape dalam usaha menutup operasional PT.IIU. Keempat adalah keberpihakan media. Kalimat "Namun, Monang yakin tak akan ada nama Ganda di saat Koran menyebutkan nama penduduk yang tewas dalam pergolakan di kampung“ menjadi penjelasan keterlibatan media masa dalam mendokumentasi dan melaporkan kasus yang diakibatkan oleh PT.IIU. Keyakinan Monang tentang tidak munculnya nama abangnya sebagai korban di Koran menunjukkan kritik Sihar sebagai pengarang terhadap Media saat itu. Keberpihakan medialah yang memungkinkan tidak semua korban jiwa yang diakibatkan oleh PT.IIU dipublikasikan. Hal inilah yang dikritik oleh Sihar. Selain itu, kedua kutipan di atas juga menjelaskan proses atau upaya yang dilakukan oleh penguasa saat itu, yaitu senjata. Dengan melibatkan senjata, penguasa melakukan intimidasi terhadap perlawanan rakyat. 


\section{Bulan Lebam di Tepian Toba: Politisasi Identitas Etnis Batak Toba}

Perubahan masyarakat Batak yang telah dianalisis sebelumnya menandakan jika satu persoalan kebatakan telah turut memengaruhi identitas etnis Batak Toba. Keadaan masyarakat Batak yang berubah menunjukkan sisi "lebam" yang ada di tepian Toba. Tentu saja, "Lebam" di sini mengindikasikan perubahan masyarakat Batak ke arah yang cenderung negatif, degradasi dan nir-makna. Di sisi lain, "lebam" yang ada adalah objektivasi tradisi sebagai objek komoditas yang hanya bernilai ekonomi saja. Dalam poin ini, Sihar turut dalam wacana kritis Batak yang berusaha merekam, merepresentasikan, dan mengkonstruksi identitas etnis Batak Toba. Dalam poin inilah, penulis melihat posisi novel yang sedang menawarkan kritik atau tawaran dalam melihat identitas etnis Batak Toba.

Hall dalam Cultural Identity and Diaspora menjelaskan persoalan identitas merupakan mekanisme produksi yang tidak akan pernah selesai. Dalam proses inilah, representasi menjadi kunci utama dalam politik identitas. Oleh karena itu, identitas akan selalu menyisakan masalah atau ruang dialog, termasuk identitas kultural atau identitas etnis. Identitas etnis Batak yang direpresentasikan dalam novel ini setidaknya membuktikan jika identitas etnis Batak Toba masih didialogkan, diproduksi, dan direproduksikan. Di sisi inilah, keterkaitan teks novel dan konteks yang melatarbelakangi (wacana kebatakan) terjalin.

Dalam melihat hal inilah, penulis meletakkan konsep Hall yang menandakan jika novel ini sedang berperan sebagai teks yang mencoba menawarkan konsep identitas etnis Batak. Terkait dengan identitas kultural, Hall (1996) kembali menegaskan :

"There are at least two different ways of thinking about cultural identity. The first position defines "cultural identity in terms of one, shared culture, a sort of collective one true self, hiding inside the many other. More superficial or artificially imposed "selves", which people with a shared history and ancestry hold in common. Whitin the terms of this definition, our cultural identities reflect the common historical experiences and shared cultural codes which provide us, as one people", with stable, unchanging and continuous frames of reference and meaning. Beneath the sifting divisions and vicissitudes of our actual history."

Kutipan ini menjelaskan identitas budaya dilihat sebagai suatu kesatuan yang dimiliki secara kolektif. Hal ini bisa ditandai dengan persamaan sejarah dan leluhur. Identitas budaya merupakan cerminan kesamaan sejarah dan kode-kode budaya yang membentuk seseorang menjadi satu kesatuan, walaupun dari "luar" mereka terlihat tidak sama sekali pun. Perspektif ini menawarkan pandangan jika identitas budaya dapat terbentuk jika melihat kesamaan sejarah dan kode budaya yang menyatukan mereka. Hal inilah yang mengidentifikasikan mereka sebagai suatu kelompok. Untuk terma pertama Hall ini yang meletakkan frasa shared culture sebagai dasarnya, novel ini pun merepresentasikan hal yang sama. Dalam awal-awal uraian narasi, dihadirkan kesamaan mitologi, kesamaan kode-kode budaya yang ada dalam novel ini.

Hal ini dapat dilihat dalam novel pada awal pengenalan tokoh Monang. Ada beberapa ritus budaya yang memang menjadi penanda identitas etnis Batak itu sendiri. Gunung Simanjarunjung, Pusuk Buhit, Danau Toba, Lembah Panatapan, rumah panggung (rumah bolon), parmalim, makam raja, dan marga-marga menjadi atribut kode-kode budaya yang dimiliki oleh manusia Batak. Gunung Simanjarunjung, Pusuk Buhit, Danau Toba, dan Lembah Penatapan merupakan kumpulan aspek alam yang memiliki fungsi baik secara 
materiil maupun kosmologi budaya. Rumah panggung, atribut kebudayaan Parmalim, Tarombo, simin, dan makam raja dan marga-marga menjadi penanda produk budaya yang ada dan masih dihidupi dalam masyarakat Batak Toba. Kesuluruhan elemen ini merupakan representasi kode-kode budaya yang menandakan identitas etnis Batak Toba.

Kode-kode budaya atau upaya shared culture yang direpresentasikan dengan jelas oleh novel ini. Sihar secara sadar meletakkan dimensi-dimensi mitologi adat, dan atribut-atribut Batak di dalamnya. Dengan kata lain, sulit untuk menyangkal jika novel ini menghadirkan identitas etnis Batak melekat dengan dimensi-dimensi ini. Setidaknya penulis merasa ungkapan "jangan sebut Batak, jika tidak menerapkan seluruh dimensi kearifan lokal manusia Batak ini" menjadi satu tawaran yang diberikan untuk menghadirkan identitas etnis Batak di dalamnya.

Stuart Hall menambahkan bahwa persoalan identitas bukanlah semata-mata berkaitan dengan eksistensi. Dalam kaitannya dengan ini pula, menurut Hall ada suatu politik identitas yang dibangun karena kompleksitas persoalan identitas yang ada. Identitas etnis yang diacu atau dirujuk dengan kesamaan konsep, penanda, atribut, dan kebersejarahan etnis dirasa oleh Hall menjadi tidak cukup lagi digunakan dalam analisis identitas.

Dalam konteks konsep identitas di atas, penulis merasa jika Sihar memiliki atau setidaknya menawarkan konsep identitas. Tentu saja, dalam hal ini, Sihar memiliki maksud atau kepentingan di dalamnya. Seperti yang telah dibahas sebelumnya jika identitas etnis pada cara pertama telah diperlihatkan dalam novel dalam bentuk penanda-penanda yang disematkan sebagai identitas etnis Batak. Hal ini menandakan jika identitas secara tradisional tidak lagi cukup. Melanjutkan penjelasan identitas Hall, (via Portcer, 2004: 118) menambakan jika :

"(The) recognition ... of the impossibility of identity in its fully unified meaning, does, of course, transform the nature of political commitment. Hundred-and-one percent commitment is no longer possible ... Looking at new conceptions of identity requires us also to look at redefinitions of the forms of politics which follow that : the politics of difference, the politics of self-reflexivity, a politics that is open to contingency but still able to act. The politics of infinite dispersal is no politics at all."

Ini berarti diperlukan konsep baru terkait identitas yang tidak lagi didasarkan pada persamaan yang tidak mengenal batas akan tetapi sebaliknya. Dituntut adanya redefinisi bentuk politik yang baru: politik pembedaan, politik refleksi diri, politik yang terbuka untuk ketidakpastian atau ketidaktetapan. Ini menandakan jika tidak ada identitas yang stabil, otonom, dan stagnan.

Ada tiga pokok bahasan utama terkait politik identitas Hall, yaitu perbedaan, refleksi diri, dan kontingensi. Politik perbedaan merangkum semua praktik yang mengakomodasi oposisi biner, hitam-putih, perempuan-pria. Dalam hal ini, perbedaan tidak ditujukan untuk mempertegas identitas diri secara eksternal (orang lain), melainkan internal. Artinya identifikasi kesamaan diri dalam satu grup atau satu kelompok (Portcer, 2004).

Konsep perbedaan ini secara khusus telah dibahas pada bagian sebelumnya pada subbab ini. Hal yang belum dibahas adalah terkait dengan oposisi biner yang dihadirkan pada novel ini. Hal ini menandakan jika "kontras" menjadi satu cara yang diambil oleh novel ini untuk memperlihatkan identitas etnis Batak Toba yang ditawarkannya. Oposisi biner yang terepresentasikan dalam novel ini bisa dilihat dari pertentangan dua entitas dalam novel ini. 
Entitas pertama adalah representasi stereotipe Batak Toba dan entitas yang memberikan "warna" baru terhadap stereotipe ini. Sihar meletakkan imaji stereotipe tentang Batak dalam menarasikan para tokohnya. Imaji stereotipe ini cenderung sesuai dengan imaji stereotipe identitas etnis Batak yang ada dalam masyarakat umum.

Konstruksi identitas yang terjadi di sini adalah upaya Sihar menghadirkan lapo tuak dalam merepresentasikan imaji stereotipe ini. Sihar melibatkan tempat sejenis "kafe rakyat" yang komoditas utamanya adalah tuak. Secara logis, tentu saja ini akan menstimulan terjadinya perilaku mabuk dan berjudi dalam masyarakat Batak Toba. Di sinilah penulis menafsirkan jika Sihar mengakui perilaku Batak yang seperti ini ada di Tanah Batak. Akan tetapi, Sihar tidak berhenti pada upaya representasi imaji stereotipe ini saja. Sihar melampauinya dengan menciptakan tokoh-tokoh narasi sebagai "identitas bandingan" atau bahkan "identitas orisinal Batak". Di sinilah oposisi biner terjadi.

Sihar menarasikan tokoh-tokoh yang tidak sesuai dengan imaji stereotipe Batak sebagai oposisi biner imaji stereotipe Batak. Dengan cara ini, novel ini tidak merepresentasikan sifat atau perilaku negatif tersebut sebagai sesuatu yang khas dari etnis Batak. Sihar menghadirkan tokoh-tokoh yang lebih positif melalui tokoh Datu.

Datu dihadirkan sebagai tokoh yang lebih positif. Datu hadir sebagai identitas etnis batak yang tradisional, identitas Batak sebelum munculnya modernitas, dan identitas Batak yang menawarkan nilai-nilai Batak yang dulu ada. Dengan kata lain, Sihar mencoba mengkonstruksi kembali identitas etnis Batak dengan bercermin pada masa lalu, pada tradisi yang memang dimiliki oleh masyarakat Batak.

Datu menjadi tokoh yang mengidentifikasi perilaku mabuk, berjudi, dan kekerasan bukanlah kebiasaan yang berasal dari tanah Batak. Perilaku-perilaku ini pun menurut Datu tidak pantas disematkan begitu saja dan berlaku hanya pada masyarakat Batak Toba. Hal ini juga disematkan dan berlaku di wilayah lain. Dengan cara ini, Sihar sedang mengupayakan jika identitas etnis Batak tidak sesuai dengan imaji stereotipe yang beredar di masyarakat umumnya.

Oposisi biner kedua adalah Tokoh Monang sebagai pemuda Batak perantauan yang mengecap pendidikan di Tanah Jawa dan memiliki pandangan kritis dan sikap politik yang jelas dihadapkan pada tokoh Muda Batak (dalam novel diwakili oleh tokoh Hotman, Rade, Tigor, dan Ganda) sebagai manusia muda Batak yang memiliki sikap mabuk-mabukan dan gemar judi serta tidak berpendidikan. Serupa dengan Datu, tokoh Monang direpresentasikan sebagai tokoh yang positif.

Tokoh Monang sendiri beroposisi biner dengan seluruh tokoh pemuda yang ada dalam novel ini. Melalui tokoh Monang, Sihar menawarkan pendidikan dan sikap kritis yang harusnya ada dalam manusia Batak. Hal inilah yang menjadi kritik Sihar jika identitas etnis Batak menurutnya bisa memasuki pendidikan dan pola pikir kritis di dalamnya.

Oposisi biner ketiga adalah tokoh Torang sebagai ayah dari Monang yang memperjuangkan hak tanah adat dan marganya berhadapan dengan tokoh Peak sebagai ayah dari tokoh Hotman yang pemabuk dan tidak "menghiraukan" persoalan adat Batak lagi. Novel ini cenderung merepresentasikan tokoh Torang sebagai identitas Batak yang lebih positif.

Oposisi biner keempat adalah representasi perubahan Tanah adat yang sebelumnya asri, bernuansa alami dan memiliki kualitas alam yang baik berhadapan dengan keadaan Kampung 
di masa sekarang ketika industri masuk dengan membawa aspal, kendaraan-kendaraan transportasi dan lonjakan perantauan yang ada di Tanah Batak. Dengan kata lain, situasi lingkungan tradisi berhadapan dengan lingkungan saat ini yang dianggap modern. Novel ini menujukkan jika keberpihakannya pada tradisi sangatlah eksplisit.

Selain dengan menghadirkan tokoh Datu dan Torang, novel ini cenderung menggunakan metode "mengingat masa lalu" sebagai cara perbedaan Batak yang dulu dan saat ini. Jika melihat keempat oposisi biner yang dihadirkan dalam novel ini, penulis cenderung menafsirkan jika identitas etnis Batak yang dibangun memiliki "warna" primordial. Ada upaya yang direpresentasikan novel ini jika kondisi kampung dan manusia Batak yang dulu lebih baik dari saat ini. Batak yang dulu dihadirkan dengan situasi lingkungan yang sehat, konteks sosial yang damai tanpa kekerasan, dan penghormatan yang tinggi pada adat dan kearifan lokal manusia Batak Toba. Inilah yang penulis simpulkan sebagai upaya penawaran identitas etnis Batak yang pertama sesuai dengan konsep Hall.

Selain konsep perbedaan, Hall menawarkan konsep refleksi diri. Konsep refleksi diri mencoba menghadirkan pemahaman jika seseorang dapat berbicara dalam posisi apapun. Refleksi diri berkonotasi dengan pemosisian (position) dalam suatu konteks. Artinya, identitas terkait dengan pemosisian yang "sengaja" dipilih seseorang untuk menunjukkan atau memperjuangkan suatu hal atau suatu kepentingan.

Jika melihat ke dalam wacana publik, kasus PT.IIU cenderung ditolak terkait operasionalnya. Hal menarik dari perlawanan yang dilakukan masyarakat Batak sejauh yang penulis observasi secara tekstual hampir seluruhnya atau dominan meletakkan pada dampak lingkungan operasional PT.IIU. Dasar perlawanannya adalah kerusakan alam yang akan menganggu ekosistem yang ada di dalamnya. Hal inilah yang berdampak pada korban jiwa, penyakit, hingga kerugian ekonomi. Dengan kata lain, perlawanan terhadap PT.IIU cenderung mengarah pada dampak lingkungan dan ekonomi saja. Dalam kerangka inilah, Sihar melakukan pemosisian dengan menghadiran implikasi yang jarang dilihat dalam pergerakan melawan PT.IIU.

Sihar dalam novel ini menunjukkan implikasi atau dampak terparah dari kasus PT.IIU, yaitu nilai tanah dalam kehidupan manusia Batak. Novel ini memperlihatkan dimensi perubahan kehidupan masyarakat Batak Toba dan masuknya kebijakan negara dan industrialisasi menyebabkan culture shock yang mampu menghilangkan "dimensi nilai dan dimensi adat" manusia Batak Toba.

Inilah yang membuat sesuatu yang sebelumnya belum pernah terjadi, kini mulai terjadi di tanah Batak. Di sinilah, Sihar mengkonstruksi satu implikasi yang nanti akan bersinggungan dengan identitas etnis Batak Toba. Ini direpresentasikan pada kutipan data berikut ini.

"Bah! Apalagi yang kamu punya?"

Tiba-tiba saja Ganda mengeluarkan sesuatu dai balik jaketnya. Hotman terkaget, berniat hendak mundur. Rade juga sempat terkaget. Walau dia tidak mengeluarkan belati, tapi ada benda lain yang tak disangka akan dibawa Ganda di tengah perjudian.

"Hei Hotman. Tenang, tenanglah kau. Yang mau kukeluarkan ini Cuma surat, takut kali kau.."

Transaksi tanah sebagai barang taruhan! 
Ganda melotot pada Hotman. (Simatupang, 2009: 12)

Ganda menatap dalam-dalam wajah Hotman.

"Ini tanahku. Aku pinjam uangmu sepuluh juta itu, Hotman. Tapi utangku yang lima juta kemarin nantilah. Sekarang, kau pegang saja surat tanahku ini...”

"Tapi aslinya itu, Ganda?"

Ganda tiba-tiba jadi merah mukanya. Kemarahan tertahan di wajah itu. ....

Ada pernyataan, ditambah cap jempol!

Memang sah!

"Benar kan? Asli, Anjing! Ha..ha.. "teriak Ganda, sambil tangannya menudingnuding Hotman (Simatupang, 2009: 13).

Kutipan di atas merupakan peristiwa yang terjadi di Lapo Tuak dengan situasi perjudian. Kutipan-kutipan ini menandakan perubahan yang cukup signifikan pada manusia Batak. Tradisi lapo tuak dengan tradisi ekonomi mengakibatkan tanah menjadi objek yang hanya bernilai materiil saja. Sihar menunjukkan jika tanah marga telah kehilangan eksistensinya di lapo tuak. Ada perubahan yang terjadi dalam Tanah Batak. Hal inilah yang digambarkan oleh Sihar dengan melibatkan perilaku mabuk dan berjudi sebagai stimulannya.

Hal lain yang menjadi kritik dalam novel ini adalah proses pemindahan hak tanah. Masyarakat Batak Toba yang sebenarnya tidak pernah membayangkan jika tanah dijadikan objek taruhan turut heran terhadap perpindahan hak milik tanah.

"Orang-orang sekampung Ganda miris mendengar kabar itu. Pertaruhan surat di tengah perjudian itu bukan khayalan melainkan kenyataan. Apalagi, kepala kampung kemudian mendukung si Hotman. Dia tidak pernah mempertanyakan bagaimana kondisi Ganda saat lelaki itu menyerahkan tanahnya. Amang Impal, kepala kampung itu, lewat restu pegawai kecamatan, telah memberikan surat keterangan untuk tanah kepada Hotman" (Simatupang, 2009: 22).

Kutipan ini merepresentasikan secara eksplisit jika orang-orang sekampung tidak pernah membayangkan akan adanya transaksi tanah adat di meja judi. Ini menandakan posisi penting tanah bagi manusia Batak. Selain itu, kehadiran tokoh Amang Impal yang direpresentasikan sebagai perwakilan PT.IIU menjadi penanda bahwa perubahan ini merupakan sesuatu yang tidak heran baginya. Legitimasi akhirnya diberikan Amang Impal sebagai penguasa birokrasi di kampung tersebut.

"Beberapa lelaki yang kepalanya belum miring oleh pengaruh tuak, melihat detail surat kumal itu. Bungkus laminating melekat di bagian surat. Surat lengkap dengan pengesahan tanda tangan pihak camat, kepala kampung, dan saksi tiga orang penduduk kampung.

"Nah, kalau soal tanda tangan Ganda, juga tanda tangan dua saksi itu, aku membawanya. Tunggu sebentar, ya."

Dikeluarkannya sebuah kertas. Kertas perjanjian terbaru mengenai pemindahan status tanah. Surat perjanjian itu juga delaminating, lebih rapi dari kertas yang pertama.

Namun, orang-orang yang di luar kawan minum Hotman tetap ragu. Tak ada kepastian untuk sah atau tidaknya surat yang disodorkan si lelaki bergigi kelam itu. Dua orang saksi yang menandatangi surat perjanjian adalah orang yang jarang terlihat di kampung ini" (Simatupang, 2009: 25).

Tokoh Hotman yang didukung oleh Amang Impal menerapkan jalur birokrasi yang telah ditentukan oleh negara. Proses perpindahan hak milik tanah ini pula yang mempertegas adanya konsep yang berbeda antara negara dan masyarakat adat terkait tanah. Memang, dalam 
kutipan ini tidak terlihat secara eksplisit perbandingan konsep ini, akan tetapi kutipan ini menunjukkan legalitas pemindahan hak milik yang mampu diskenariokan. Hal ini tentu berbanding terbalik dengan konsep tanah di huta yang ada.

Tanah sendiri merupakan dimensi yang akan menjamin kehidupan Batak pada generasi berikutnya karena sifat kepemilikannya hanya bisa dilakukan dengan pewarisan. Hal inilah yang semakin menandakan jika tanah tidak dapat diartikan sebagai unsur materil fisik saja, akan tetapi juga menyentuh aspek hukum dan konteks kesosialan masyarakat Batak Toba. Hal inilah yang jelas tampak pada kutipan di bawah ini.

"Perdebatan tanah ketika Hotman hendak meminta hasil judinya kepada tokoh

\section{Torang.}

“Tetapi ladang tiga ribu meter itu kini milik kami!"tuding Hotman.

"Itu tanah margaku, tahu kau!" balas Torang tak kalah kerasnya.

Torang merasa dirinya dilecehkan dan tak dihormati. Dia orangtua, beraninya Hotman menuding dia dengan telunjuk. Itu tidak sopan!

Tanah tiga ribu meter di sebelah barat kampungnya itu adalah miliknya. Tanah perjuangan, itu tanah Ompung-nya, ditambah tanah hasil keringatnya bertani selama ini. Separuh tanah itu jelas milik Torang, selamanya dia berhak atas tanah itu.

Apa-apaan ini? Judi yang merampok tanah adat!

Dia tak pernah menjual tanah itu!

Tak pernah!(Simatupang, 2009: 28)

Kutipan ini menjadi representasi pentingnya tanah bagi masyarakat Batak Toba. Torang menjadi satu-satunya tokoh dalam novel ini yang mengingatkan jika tanah tidak hanya berdimensi ekonomi atau materiil saja. Hal ini tentu saja sejalan sengan konsep huta bagi masyarakat Batak. Konsep inilah yang menghadirkan dimensi jika tanah bagi masyarakat batak memiliki nilai di dalamnya. Di sinilah Sihar hadir dengan mempersoalkan hal ini. Secara narasi, Sihar menempatkan PT.IIU sebagai penguasa yang berhasil memengaruhi manusia Batak; tokoh Amang Impal dan Hotman. Sihar mengkonstruksi realita melalui fiksinya dengan mencoba memasukkan dimensi tanah dalam arus pertikaian konflik cerita.

Implikasi paling parah adalah orientasi ekonomi menjadi muara yang akan ditempuh oleh perilaku-perilaku ini. Seluruh hal yang ada dapat diobjektivasi dan dilihat harga ekonomisnya. Hal inilah yang dibangun Sihar dengan menempatkan "surat tanah" sebagai bahan perjudian. Sihar mencoba menampilkan jika perubahan perilaku dalam masyarakat Batak Toba yang cenderung mengarah kepada perjudian dan mabuk dapat menyebabkan persoalan-persoalan yang sebelumnya tidak terpikirkan sama sekali oleh generasi pendahulunya.

Sihar menghubungkan tiga hal dalam membangun kritiknya. Ia memasukkan tiga hal ini dalam unsur pembangun narasinya. Unsur pertama adalah pendidikan. Pemuda batak yang dihadirkan berperilaku mabuk dan berjudi merupakan hasil corak pendidikan yang ada dalam masyarakat di kampung tersebut. Corak pendidikan ini sendiri telah direpresentasi melalui tokoh Torang dan istrinya (orang tua Monang) yang meletakkan hasil akhirnya pada ijazah dan pekerjaan (kekayaan/hamoraon). Intinya adalah pendidikan yang pragmatis hanya menghasilkan logika ekonomi atau angka sebagai hasilnya. Inilah yang terjadi pada pemudapemuda Batak, Amang Impal, dan Hotman. Tentu saja ini juga menjadi hasil dari modernitas yang dikritik oleh Sihar itu sendiri. 
Unsur kedua adalah perilaku yang sesuai imaji stereotipe identitas Batak dalam masyarakat umum. Sihar menghadirkan perilaku-perilaku ini sebagai stimulan masalah tanah. Unsur ketiga adalah pihak industri. Pihak industri (PT.IIU/pabrik kertas) direpresentasikan sebagai penguasa yang dapat menawarkan logika ekonomi yang lebih besar bagi manusia Batak. Pihak ini pula yang penulis tafsirkan mampu memanfaatkan kelemahan pada unsur pertama dan kedua dalam menjalankan misinya. Ketiga hal inilah yang terhubung dan menjadi jalinan kritik Sihar.

Perilaku, sikap dan corak pandang para tokoh yang dinarasikan Sihar diidentifikasi sebagai sumber masalah dalam penguasaan lahan pabrik kertas. Kritik sihar di sini menjadi unik karena memang tidak banyak yang mengambil topik dan pemosisian kasus PT IIU dilihat dari dimensi perilaku, pendidikan, dan adat Batak sebagai hal-hal yang bersinggungan dengan PT.IIU.

Ketiga unsur yang penulis sebutkan tadi juga sekaligus menjadi unsur pembangun tawaran Sihar terkait persoalan PT.IIU. Unsur pendidikan menjadi poin yang direpresentasikan oleh Sihar perlu dibenahi. Pendidikan yang berlaku selama ini (melalui tokoh orang tua Monang) cenderung pragmatis dan tidak bisa menandingi persoalan PT.IIU. Dalam rangka inilah, Sihar menghadirkan tokoh Monang dengan corak berpikir pembaharuan, perantau yang aktif dalam pemolesan pola pikir kritis, dan mau bergerak secara politik. Identitas etnis Batak yang terlihat di sini cenderung identitas etnis Batak yang visioner dan tidak apolitis. Hal ini menjadi tawaran Sihar dalam persoalan PT.IIU. Sesuai dengan konsep diferensiasi, Sihar merepresentasikan penangkapan tokoh Amang Impal dan Hotman menjadi penanda jika corak berpikir ala Monang mampu menjadi alternatif dalam melawan PT.IIU.

Selain itu, Sihar mengkonstruksi kritiknya dengan menghadirkan tokoh Datu sebagai penyeimbang Monang. Melalui tokoh Datu, Sihar memberi wacana jika "kembali pada tradisi” Batak juga perlu dilakukan. Hal inilah yang akan memungkinkan lahirnya kembali relasi manusia Batak dan adatnya, serta kolektivitas Batak yang semakin erat sehingga menjadi satu cara efektif menghalau wacana industri yang datang.

Kedua tokoh inilah yang menjadi suara atau identitas etnis tawaran Sihar dalam menghadapi perubahan dan persoalan PT.IIU. Sihar menawarkan jika "kembali" pada tradisi dan diimbangi dengan pemikiran kritis serta gerakan politik akan mampu menandingi wacana PT.IIU. Tawaran in tentu saja menjadi upaya polik identitasnya. Sihar menyuarakan pemikiran kebatakannya dengan tradisi dan pemikiran kritis sebagai penanda identitas etnis Batak.

\section{Simpulan}

Dari pembahasan yang telah dilakukan, ada beberapa hal yang dapt dirangkum. Pertama, persoalan PT.IIU terpresentasikan secara eksplisit dalam novel ini. Persolan inipun meliputi perubahan sosial masyarakat Batak Toba. Kedua, Novel ini menawarkan sejumlah kritikan terhadap eksistensi PT.IIU. Tepat pada poin inilah politik identitas etnis Batak Toba kembali ditekankan dalam novel ini. Tentu saja, kaitannya khusus pada eksistensi problem PT.IIU dalam novel. Kritikan yang dibangun dalam novel ini merupakan penolakan massif yang dilakukan oleh mayoritas tokoh dalam narasi ini. PT.IIU dihadirkan sebagai sumber masalah dengan citra negatif yang dihadirkan melalui pengkaraktertan tokoh Amang Impal 
dan Hotman. Keterlibatan manusia Batak dalam jaringan kekuasaan PT.IIU pun menjadi kritik dalam novel ini.

PT.IIU dalam novel ini menjadi akar persoalan yang mampu menjauhkan jarak tanah adat dalam kehidupan manusia Batak. Hal inilah yang dipadukan dengan kebiasaan para tokoh untuk mabuk-mabukan dan berjudi sehingga memudahkan PT.IIU menguasai lahan di Tanah Batak. Dalam proses perubahan inilah, tokoh-tokoh dalam novel melakukan identifikasi terhadap identitas etnis Batak. Pertama adalah identitas etnis pertama yang ditawarkan Hall sebagai kesamaan kode-kode kebudayaan dan shared culture. Hal kedua adalah pemosisian yang terangkum dalam konsep refleksi diri. Di sini telah terlihat jika tokoh Datu, Tesya, dan Monang menjadi "ruang pembentukan" identitas etnis Batak yang ditawarkan oleh novel ini. Novel ini sebenarnya dapat diletakkan sebagai konsep tambahan yang ditawarkan oleh Hall dalam politik identitas, yaitu politik artikulasi. Novel ini menjadi artikulasi pengaran untuk ikut ambil bagian dan mencoba menawarkan identitas etnis Batak Toba. Alhasil, politik identitas etnis Batak yang dihadirkan adalah etnisitas Batak yang dilekatkan pada perdamaian, kejujuran, berpendidikan, berpikir kritis, dan melawan PT.IIU.

Melalui novel ini, Sihar (pengarang) melakukan politik artikulasi (politics of articulation) yang mencoba mengakomodasi pemikirannya terkait persoalan PT.IIU dan perubahan sosial yang terjadi di Tanah Batak. Konsep politik identitas Hall yang berbicara soal kontingensi merupakan hal yang juga diperlihatkan dalam novel ini. Perjuangan tokoh Ganda dan seluruh warga kampung jelas memerlihatkan kontingensi kebatakan yang ada. Artinya, ada kepentingan Batak yang sama dan dirasa perlu diperjuangkan.

Dalam kaitannya dengan PT.IIU, novel ini juga menawarkan pemikiran kritis dan masuk dalam ranah politiklah yang mampu menjadi wacana bandingan terhadap operasional PT.IIU. Dengan kata lain, identitas etnis Batak menjadi sesuatu yang kompleks karena akan selalu menghadirkan "ruang" kepentingan di dalamnya. Di sinilah letak konsep kontingensi yang ditawarkan Hall, selain diferensiasi dan refleksi diri. Novel ini jelas hadir dalam dinamika ini. Novel ini cenderung menawarkan satu gerakan kembali pada "tradisi" yang harus dipadukan dengan pendidikan dan pola pikir kritis yang harus dimiliki oleh manusia Batak dalam perjuangannya menghadapi wacana industri atau dalam terminologi tokoh Datu yang bernada "lebam" adalah peradaban. Di poin inilah, Sihar sedang mengupayakan politik identitas etnis Batak.

\section{Daftar Pustaka}

Barker, C. (2000). Cultural Studies, Theory, and Practice. London: Sage Publication

Hall, S. (1990). Identity : Community, Culture, Difference. Jonathan Rutherford (Ed). UK: Lawrence \& Wishart.

. (1993). "Cultural Identity and Diaspora", in P. Williams and L. Chrisman (Ed)

Colonial Discourse and Post-colonial Theory. London: Harvester Wheatsheaf.

(1996). "New Etnicities" in D Morley and D.K. Chen (ed). Stuart Hall.London: Routledge.

Klenden, I. (2004). Sastra Indonesia dalam Enam Pertanyaan.Jakarta: Grafiti

Manalu, D. (2009). Gerakan Sosial dan Perubahan Kebijakan Publik: Studi Kasus Gerakan Perlawanan Masyarakat Batak VS PT. Indorayon Utama di Sumatera 
Utara.Yogyakarta: Gadjah Mada University Press Bekerja sama dengan Kelompok Studi dan Pengembangan Prakarsa Masyarakat.

Neuendorf, K.A. (2002). The Content Analysis Guidebook. London : Sage Procter, J. (2004). Stuart Hall. London: Routledge

Simatupang, S. R. (2009). Bulan Lebam di Tepian Toba. Jakarta : Kakilangit Kencana. 